\title{
Strontium Titanate-based Composite Anodes for Solid Oxide Fuel Cells
}

\author{
Blennow Tullmar, Peter; Kammer Hansen, Kent; Wallenberg, L.R.; Mogensen, Mogens Bjerg
}

Published in:

ECS Transactions

Link to article, DOI:

$10.1149 / 1.3050390$

Publication date:

2008

Document Version

Publisher's PDF, also known as Version of record

Link back to DTU Orbit

Citation (APA):

Blennow Tullmar, P., Kammer Hansen, K., Wallenberg, L. R., \& Mogensen, M. B. (2008). Strontium Titanatebased Composite Anodes for Solid Oxide Fuel Cells. ECS Transactions, 13(26), 181-194.

https://doi.org/10.1149/1.3050390

\section{General rights}

Copyright and moral rights for the publications made accessible in the public portal are retained by the authors and/or other copyright owners and it is a condition of accessing publications that users recognise and abide by the legal requirements associated with these rights.

- Users may download and print one copy of any publication from the public portal for the purpose of private study or research.

- You may not further distribute the material or use it for any profit-making activity or commercial gain

- You may freely distribute the URL identifying the publication in the public portal 


\title{
Strontium Titanate-based Composite Anodes for Solid Oxide Fuel Cells
}

\author{
Peter Blennow $^{\mathrm{a}}$, Kent K. Hansen ${ }^{\mathrm{a}}$, L. Reine Wallenberg ${ }^{\mathrm{b}}$, Mogens Mogensen ${ }^{\mathrm{a}}$ \\ ${ }^{a}$ Fuel Cells and Solid State Chemistry Department, Risø National Laboratory for \\ Sustainable Energy, Technical University of Denmark, DK-4000 Roskilde, Denmark \\ ${ }^{\mathrm{b}}$ nCHREM, Polymer and Materials Chemistry, Kemicentrum, Lund University, P.O. Box \\ 124, SE-221 00 Lund, Sweden
}

\begin{abstract}
Surfactant-assisted infiltration of Gd-doped ceria (CGO) in $\mathrm{Nb}$ doped $\mathrm{SrTiO}_{3}(\mathrm{STN})$ was investigated as a potential fuel electrode for solid oxide fuel cells (SOFC). An electronically conductive backbone structure of STN was first fabricated at high temperatures and then combined with the mixed conducting and electrochemically active nano-sized CGO phase at low temperatures. Symmetrical cell measurements at open circuit voltage (OCV), showed that the electrochemical activity was maintained or even improved compared to Ni/YSZ fuel electrodes. The novel electrode had an electrode polarization resistance of $0.12 \Omega \mathrm{cm}^{2}$ and $0.44 \Omega \mathrm{cm}^{2}$ in humidified $\mathrm{H}_{2}$ at $850{ }^{\circ} \mathrm{C}$ and $650{ }^{\circ} \mathrm{C}$, respectively. In addition, the ceramic composite electrode was shown to be redox stable. The electrode was actually activated with redox cycles at $650{ }^{\circ} \mathrm{C}$. The ceramic electrode structure thus presents a potential solution to overcome some of the major limitations of the current Ni-YSZ cermet SOFC anodes.
\end{abstract}

\section{Introduction}

Solid oxide fuel cells (SOFC) are high temperature electrochemical devices, which convert the energy of a chemical reaction directly into electrical energy. They are normally operated between $600-1000{ }^{\circ} \mathrm{C}$. Most developers of SOFCs use anodes that are a ceramic-metallic composite (cermet) of yttria-doped zirconia (YSZ), a polycrystalline ceramic that conducts oxygen ions, and nickel. The nickel-based fuel electrodes are capable of outstanding performance in hydrogen or syngas (a mixture of $\mathrm{H}_{2}$ and $\mathrm{CO}$ usually formed by hydrocarbon reforming). However, at elevated temperatures nickel tends to agglomerate and sinter, resulting in a degradation of the anode performance with time. The Ni-YSZ anode degrades during redox cycles (1) and impurities in the fuel stream, particularly sulphur (2), inhibit anode functionality. Therefore, it would be advantageous to develop alternative anode materials or compositions to overcome the problems associated with Ni-YSZ.

Several authors have indicated that anodes based on a perovskite structure are promising candidates for future fuel cell anodes (3-5). Recently, ceramic composites with La-doped strontium titanate and doped ceria, sintered at high temperatures, have been reported to show promising electrocatalytic and conductivity results appropriate for SOFC applications (6). The doped strontium titanate composite anodes were tolerant to oxygen-, carbon, and sulphur-containing atmospheres. Other research groups have reported that titanate-based anodes were remarkably active for the oxidation of $\mathrm{CH}_{4}$ at high temperatures in the absence of excess steam (7). Some n-doped titanates have also 
been found to be dimensionally phase stable during redox cyclings, but the electrocatalytic activity for $\mathrm{H}_{2}$ oxidation was poor $(8,9)$. Other titanates were tolerant to extremely high sulfur-containing (up to $1 \% \mathrm{H}_{2} \mathrm{~S}$ ) fuel atmospheres (10). Thermodynamic calculations and experiments indicated that $\mathrm{SrTiO}_{3}$ was thermodynamically stable in $10 \% \mathrm{H}_{2} \mathrm{~S} / 3 \% \mathrm{H}_{2} \mathrm{O} / 87 \% \mathrm{H}_{2}$. The titanate did not react with the sulfur even after 5 days exposure at $950{ }^{\circ} \mathrm{C}$ (11). La-doped $\mathrm{SrTiO}_{3}$ with some $\mathrm{Mn}$ substituting for Ti (12) and La-doped $\mathrm{SrTiO}_{3}$ with small additions of $\mathrm{Mn}$ and $\mathrm{Ga}$ on the Ti-site (7) have also shown to be promising anode materials for SOFC. Similarly, a high-level Mn-doped lanthanum strontium chromite, was reported to achieve rather good electrochemical performance $(13,14)$. However, the absence of very high conductivity in fuel conditions might impede their use as fuel electrodes in SOFC applications. In general, it has been difficult to achieve sufficient conductivity and performance in single-component materials leading to an apparent need for a composite or cermet approach.

Infiltration of various materials has recently been introduced for use in SOFC electrodes. Cu-ceria infiltration into a YSZ backbone structure has been reported largely from the work by Gorte et al. (15). The primary goal to use $\mathrm{Cu}$ instead of $\mathrm{Ni}$, was direct utilization of hydrocarbons. In the $\mathrm{Cu}$-based anodes, $\mathrm{Cu}$ is believed only to provide electronic conductivity, while ceria is the mixed conductor and oxidation catalyst responsible for electrochemical oxidation of the fuel. The Mn-doped lanthanum strontium chromite $\left(\mathrm{La}_{0.75} \mathrm{Sr}_{0.25} \mathrm{Mn}_{0.5} \mathrm{Cr}_{0.5} \mathrm{O}_{3}\right)$ investigated by Tao and Irvine $(13,14)$, has been infiltrated with Gd-doped ceria by other research groups, where they reported that an improved performance in various fuels was achieved $(16,17)$. Infiltration with ceria nanoparticles, in Ni-YSZ based anodes, has also showed sustained sulphur tolerance when operating on humidified $\mathrm{H}_{2}$ fuel containing 40 ppm $\mathrm{H}_{2} \mathrm{~S}$ (18).

$\mathrm{Nb}$-doped $\mathrm{SrTiO}_{3}$ has been shown to have high electronic conductivity and promising redox stability. However, it had very low electrocatalytic activity for oxidation of hydrogen (8). In this work it will be shown that it is possible to improve the performance for hydrogen oxidation by several orders of magnitude through surfactant-assisted infiltration of a Gd-doped ceria phase (CGO), which after low-temperature calcination form nano-sized CGO particles on the surface of the $\mathrm{Nb}$-doped $\mathrm{SrTiO}_{3}$.

\section{Experimental}

\section{$\underline{\text { Sample Preparation }}$}

Vacancy-compensated $\mathrm{Nb}$-doped strontium titanate with extra A-site deficiency, nominal composition $=\mathrm{Sr}_{0.94} \mathrm{Ti}_{0.9} \mathrm{Nb}_{0.1} \mathrm{O}_{3}(\mathrm{STN})$, was synthesized by a modified glycine nitrate combustion process. A detailed description of the synthesis is published elsewhere (19). The powder ash that formed after the synthesis was calcined in air at $900{ }^{\circ} \mathrm{C}$ for $2 \mathrm{~h}$.

Two different slurries were subsequently fabricated; one with STN and one with STN in a composite with a commercial YSZ powder (Tosoh, TZ8Y), 1:1 by weight (approximately $54 / 46 \mathrm{vol} \%$ ratio). TZ8Y was also used to prepare presintered YSZ electrolyte foils ( $5 \times 5 \mathrm{~cm}^{2}$, ca: $200 \mu \mathrm{m}$ thick). The electrode materials were applied onto both sides (symmetrical cells) of the presintered YSZ electrolyte substrates by spraying. The sprayed cells were sintered in air at $1250{ }^{\circ} \mathrm{C}$ for $3 \mathrm{~h}$. The thickness of the porous 
electrode layers was between $15-30 \mu \mathrm{m}$ after sintering. The as-fabricated cells were cut into smaller cells, either $0.4 \times 0.4 \mathrm{~cm}^{2}$ or $0.6 \times 0.6 \mathrm{~cm}^{2}$. After cutting, some symmetrical cells were sintered a second time at $1300^{\circ} \mathrm{C}$ in air for $3 \mathrm{~h}$ (see Table I).

An infiltration solution of $\mathrm{Ce}_{0.8} \mathrm{Gd}_{0.2} \mathrm{O}_{2-\delta}(\mathrm{CGO})$ precursor was prepared by dissolving 0.008 mole cerium nitrate $\left(3.474 \mathrm{~g} \mathrm{Ce}\left(\mathrm{NO}_{3}\right)_{3} \cdot 6 \mathrm{H}_{2} \mathrm{O}\right.$ (Alfa Aesar)) and 0.002 mole gadolinium nitrate $\left(0.902 \mathrm{~g} \mathrm{Gd}\left(\mathrm{NO}_{3}\right)_{3} \cdot 6 \mathrm{H}_{2} \mathrm{O}\right.$ (Alfa Aesar)) in ca: $10 \mathrm{~g}$ ethanol. A polymeric surfactant was then dissolved in the nitrate solution at room temperature. The prepared solution was infiltrated into the open porosities of the different sintered electrodes using vacuum infiltration. After infiltration, the cells were calcined at $350{ }^{\circ} \mathrm{C}$ in air for $4 \mathrm{~h}$. The infiltration step with subsequent calcination was repeated three times. The applied amount of CGO in the porous electrodes was estimated by weighing the cells before and after impregnation and calcination. The approximate weight of the electrolyte was subtracted to get wt \% of CGO in the electrode.

\section{$\underline{\text { Sample Characterization }}$}

The phase identification of infiltrated samples was carried out using X-ray diffraction (XRD). X-ray diffractograms were collected at $20^{\circ} \leq 2 \theta \leq 90^{\circ}$ using $\mathrm{Cu} \mathrm{K}_{\alpha}$ radiation (40 $\mathrm{kV}$ and $30 \mathrm{~mA}$ ) with a STOE Theta-Theta diffractometer. XRD was performed on symmetrical cells consisting of YSZ as the electrolyte and STN as the backbone structure which had been impregnated with the CGO solution three times. Some cells were further heated to various temperatures between $650-850^{\circ} \mathrm{C}$ for $48 \mathrm{~h}$ in different atmospheres (either air or $9 \% \mathrm{H}_{2} / \mathrm{N}_{2}$ ) to investigate their effect on grain size and microstructure. The average grain size $d_{\text {avg }}$ was calculated from the diffractograms using Scherrer's Eq. [1]:

$$
d_{\text {avg }} \approx \frac{\kappa \cdot \lambda}{\beta \cdot \cos (\theta)}
$$

where $\kappa, \lambda, \beta$, and $\theta$ are the shape factor (taken as 0.9 ), the wave length of the $\mathrm{Cu} \mathrm{K}_{\alpha}$ radiation (1.54056 $\AA$ ), the full width at half maximum (FWHM), and the Bragg angle, respectively.

Nitrogen adsorption/desorption experiments (BET) were conducted on various infiltrated samples in order to determine the specific surface area (SSA) and how it was affected by different temperatures and atmospheres. The samples were measured on a Micromeritics ASAP 2400 V3.06, where all samples were de-gassed in vacuum at $300{ }^{\circ} \mathrm{C}$ for $16 \mathrm{~h}$ prior to adsorption. The BET specific surface areas were calculated from the adsorption isotherm keeping the values of the relative $\mathrm{N}_{2}$ pressure $\left(p / p_{0}\right)$ between $0.05-$ 0.21 for all samples.

The microstructure of infiltrated cells, both before and after electrochemical characterization, was investigated on fractured cells with a JEOL JSM-6700F scanning electron microscope (SEM) equipped with an x-ray energy dispersive spectrometer (XEDS). Some infiltrated samples was also characterized by transmission electron microscopy (TEM) on a JEOL 3000F. For the TEM investigations, the CGO-infiltrated and calcined STN-electrode was scraped off from the electrolyte and the resulting powder was suspended in ethanol and transferred to a copper-carbon grid by dipping into the solution. 


\section{Electrochemical Characterization}

The electrode polarization resistance $\left(\mathrm{R}_{\mathrm{P}}\right)$ of various infiltrated electrodes with STN or STN/YSZ backbone structure on symmetrical cells (see Table I) has been characterized by electrochemical impedance spectroscopy (EIS) in a one-atmosphere setup. Before EIS measurements, Pt-paste was applied onto the electrodes to obtain a current collection layer. The edges of the symmetrical cells were also gently polished to ensure no current leakage between the two electrode layers due to CGO deposition on the edges from the infiltration procedure. Measurements were conducted between $600-850$ ${ }^{\circ} \mathrm{C}$ in various atmospheres with water-saturated (at ambient temperature) $\mathrm{H}_{2} / \mathrm{N}_{2}$ gas mixtures.

Some symmetrical cell samples were also subjected to numerous redox cycles in order to investigate the redox stability of the various electrodes and to simulate the effect of loss of hydrogen fuel during SOFC operation. One redox cycle involved changing the atmosphere from reducing (humidified $\mathrm{H}_{2}$ ) to completely oxidizing (air) at $650-850{ }^{\circ} \mathrm{C}$. The oxidizing atmosphere was maintained for $0.5-2.5 \mathrm{~h}$ and then the gas was switched back to humidified $\mathrm{H}_{2}$ again. The impedance response was subsequently monitored as a function of time from re-reduction. The oxygen partial pressure $\left(P\left(\mathrm{O}_{2}\right)\right)$ was monitored in-situ during the measurements. The impedance spectra of the symmetrical cells were obtained at open circuit potential (OCP) with a Solartron 1260 FRA (frequency range 1 $\mathrm{MHz}-50 \mathrm{mHz}$ with $25 \mathrm{mV}$ amplitude). The impedance data were analyzed with ZSimpWin software (EChem Software).

Table I. Symmetrical cell types fabricated and tested. STN $=\mathrm{Sr}_{0.94} \mathrm{Ti}_{0.9} \mathrm{Nb}_{0.1} \mathrm{O}_{3} ; \mathrm{CGO}=$ $\mathrm{Ce}_{0.8} \mathrm{Gd}_{0.2} \mathrm{O}_{2-\delta} ; \mathrm{YSZ}=\mathrm{TZ} 8 \mathrm{Y}$ (Tosoh). STN_CGO-1 and STN_CGO-2 were similar cells fabricated as two separate batches for reproducibility tests.

\begin{tabular}{|c|c|c|c|}
\hline \multicolumn{2}{|c|}{ Electrode composition } & \multirow[b]{2}{*}{ Abbreviation } & \multirow[b]{2}{*}{$\begin{array}{c}\text { Backbone sintering } \\
\text { temperature }\end{array}$} \\
\hline $\begin{array}{l}\text { Backbone } \\
\text { structure }\end{array}$ & $\begin{array}{c}\text { Infiltrated } \\
\text { phase }\end{array}$ & & \\
\hline STN & CGO & STN_CGO-1 & $1250^{\circ} \mathrm{C} / 3 \mathrm{~h}$ \\
\hline STN & $\mathrm{CGO}$ & STN_CGO-2 & $1250^{\circ} \mathrm{C} / 3 \mathrm{~h}$ \\
\hline STN & $\mathrm{CGO}$ & STN(1300)_CGO & $1250^{\circ} \mathrm{C} / 3 \mathrm{~h}+1300^{\circ} \mathrm{C} / 3 \mathrm{~h}$ \\
\hline STN/YSZ & CGO & STN/YSZ(1300)_CGO & $1250^{\circ} \mathrm{C} / 3 \mathrm{~h}+1300^{\circ} \mathrm{C} / 3 \mathrm{~h}$ \\
\hline
\end{tabular}

\section{Results}

\section{$\underline{\text { Sample Characterization }}$}

The CGO content in the infiltrated electrodes was calculated by weighing the small symmetrical cells before and after the three infiltration steps on two different symmetrical cell types. The CGO content was measured on four STN(1300)_CGO ( 4 x $\left.4 \mathrm{~mm}^{2}\right)$ cells and on six STN_CGO-1 $\left(6 \times 6 \mathrm{~mm}^{2}\right)$ cells to be $21.6 \pm 3 \mathrm{wt} \%$ and $27.9 \pm 3 \mathrm{wt} \%$, repectively.

Figure 1 display high magnification SEM images of the microstructure of a fractured symmetrical cell with the STN backbone electrode (STN(1300)_CGO) infiltrated three 
times with the CGO precursor solution. The nano-sized CGO particles completely covered all the STN particles in the porous microstructure all the way into the electrolyte.
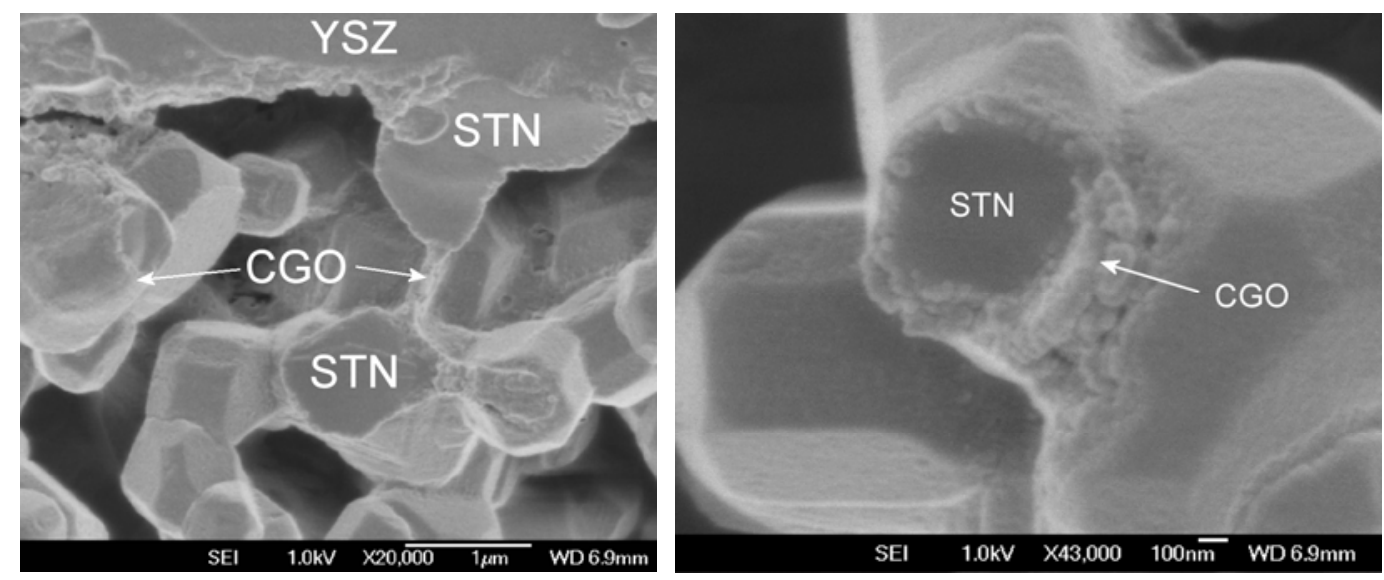

Figure 1. Cross-sectional SEM images at various magnifications of STN backbone (on a YSZ electrolyte) infiltrated with CGO precursor solution three times (cell type: STN(1300)_CGO). The CGO particles are seen as the thin layer $(50-100 \mathrm{~nm})$ covering the surfaces of the larger STN particles.

XRD investigation was performed on symmetrical cells consisting of YSZ as the electrolyte and STN as the backbone structure which had been impregnated with the CGO solution (similar to cell type STN_CGO-1) and calcined at various temperatures and atmospheres for $12-48 \mathrm{~h}$. The diffractograms are seen in Figure 2.

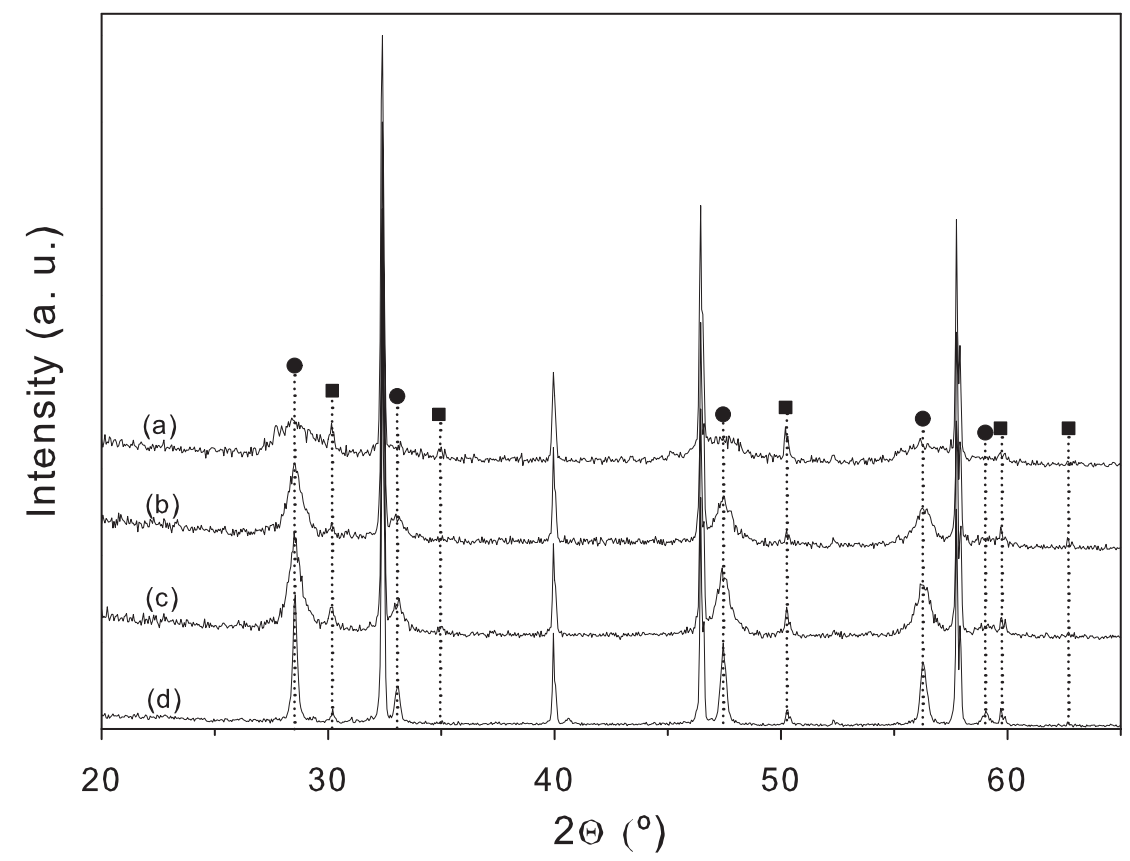

Figure 2. XRD patterns of symmetrical cells (a) after infiltration three times with CGO precursor solution with subsequent calcination at $350{ }^{\circ} \mathrm{C}$ in air for $4 \mathrm{~h}$. (b) same as (a) with further heating at $650{ }^{\circ} \mathrm{C}$ in air for $48 \mathrm{~h}$. (c) same as (a) with further heating at 650 ${ }^{\circ} \mathrm{C}$ in $9 \% \mathrm{H}_{2} / \mathrm{N}_{2}$ for $48 \mathrm{~h}$. (d) same as (a) with further heating at $850{ }^{\circ} \mathrm{C}$ in $9 \% \mathrm{H}_{2} / \mathrm{N}_{2}$ 
for $48 \mathrm{~h}$. Solid circles represent CGO peaks. Solid squares represent YSZ peaks from the electrolyte. Unmarked peaks are STN perovskite phase.

There were clear broad peaks in the diffractograms indicating small grain sizes of CGO. From the difference in peak broadening of the CGO peaks, it was clear that both the temperature and the gas composition had an effect on the particle size of the calcined CGO phase. The average grain sizes were calculated from Eq. [1] and are shown in Table II. The average grain size of CGO was only about $5 \mathrm{~nm}$ after infiltration and calcination at $350{ }^{\circ} \mathrm{C}$ and reached a grain size of approximately $40 \mathrm{~nm}$ after further heating at $850{ }^{\circ} \mathrm{C}$ in $9 \% \mathrm{H}_{2} / \mathrm{N}_{2}$ for $48 \mathrm{~h}$.

The specific surface area (SSA) results from the nitrogen adsorption/desorption experiments are displayed in Table II. The BET SSA were compared with calculated specific surface areas (SSA (XRD)) where the BET data from the single component STN material was combined with the theoretical specific surface area from the CGO particles by assuming spherical CGO particles with the grain sizes determined from Scherrer broadening (see Eq. (1)). The SSA (XRD) (see Table II) was thus calculated according to Eq. [2] by assuming $75 \mathrm{wt} \% \mathrm{STN}$ and $25 \mathrm{wt} \%$ CGO in the composite (average CGO content in the electrode).

$$
S S A(X R D)=0.75 \cdot S S A_{S T N}(B E T)+0.25 \cdot \frac{6}{d \cdot \rho}
$$

$S S A_{S T N}(B E T)$ is the specific surface area of $\mathrm{Nb}$-doped $\mathrm{SrTiO}_{3}$ determined from BET measurements (approximately $11 \mathrm{~m}^{2} / \mathrm{g}$ ) and $d$ and $\rho$ are the average grain size of the CGO particles (determined from Eq [1]) and the density of CGO $\left(7.26 \mathrm{~g} / \mathrm{cm}^{3}\right)$, respectively.

Table II. Calculated grain size of the CGO particles from XRD together with BET specific surface area (SSA) of the samples with approximately $75 \mathrm{wt} \%$ STN and $25 \mathrm{wt} \%$ CGO. Single component Nb-doped $\mathrm{SrTiO}_{3}$ had a BET SSA of approximately $11 \mathrm{~m}^{2} / \mathrm{g}$. The SSA (XRD) values were calculated by Eq. [2].

\begin{tabular}{lcccc}
\hline Temperature $\left({ }^{\mathbf{0}} \mathbf{C}\right)$ & Atmosphere & $\begin{array}{c}\text { Average grain size } \\
\text { from XRD }(\mathbf{n m})\end{array}$ & $\begin{array}{c}\text { BET SSA } \\
\left(\mathbf{m}^{2} / \mathbf{g}\right)\end{array}$ & $\begin{array}{c}\text { SSA (XRD) } \\
\left(\mathbf{m}^{2} / \mathbf{g}\right)\end{array}$ \\
\hline $350($ total time $=12 \mathrm{~h})$ & Air & 5 & $54.5 \pm 0.2$ & $\sim 50$ \\
$650(48 \mathrm{~h})$ & Air & 12 & $19.6 \pm 0.2$ & $\sim 25$ \\
$650(48 \mathrm{~h})$ & $9 \% \mathrm{H} 2 / \mathrm{N} 2$ & 16 & $12.3 \pm 0.1$ & $\sim 21$ \\
$850(48 \mathrm{~h})$ & $9 \% \mathrm{H} 2 / \mathrm{N} 2$ & 38 & $7.8 \pm 0.1$ & $\sim 14$ \\
\hline
\end{tabular}

The samples calcined at $350{ }^{\circ} \mathrm{C}$ in air and at $650{ }^{\circ} \mathrm{C}$ in $9 \% \mathrm{H}_{2} / \mathrm{N}_{2}$ were also investigated with TEM (see Figure 3). The TEM images confirm the grain size calculations from XRD. After calcination at $350{ }^{\circ} \mathrm{C}$ the average CGO grain size was approximately $5 \mathrm{~nm}$ (see Figure $3 \mathrm{~A}$ ) and after calcination at $650{ }^{\circ} \mathrm{C}$ in $9 \% \mathrm{H}_{2} / \mathrm{N}_{2}$ for 48 $\mathrm{h}$ the average grain size appeared to be around $20 \mathrm{~nm}$ (see Figure 3B). 

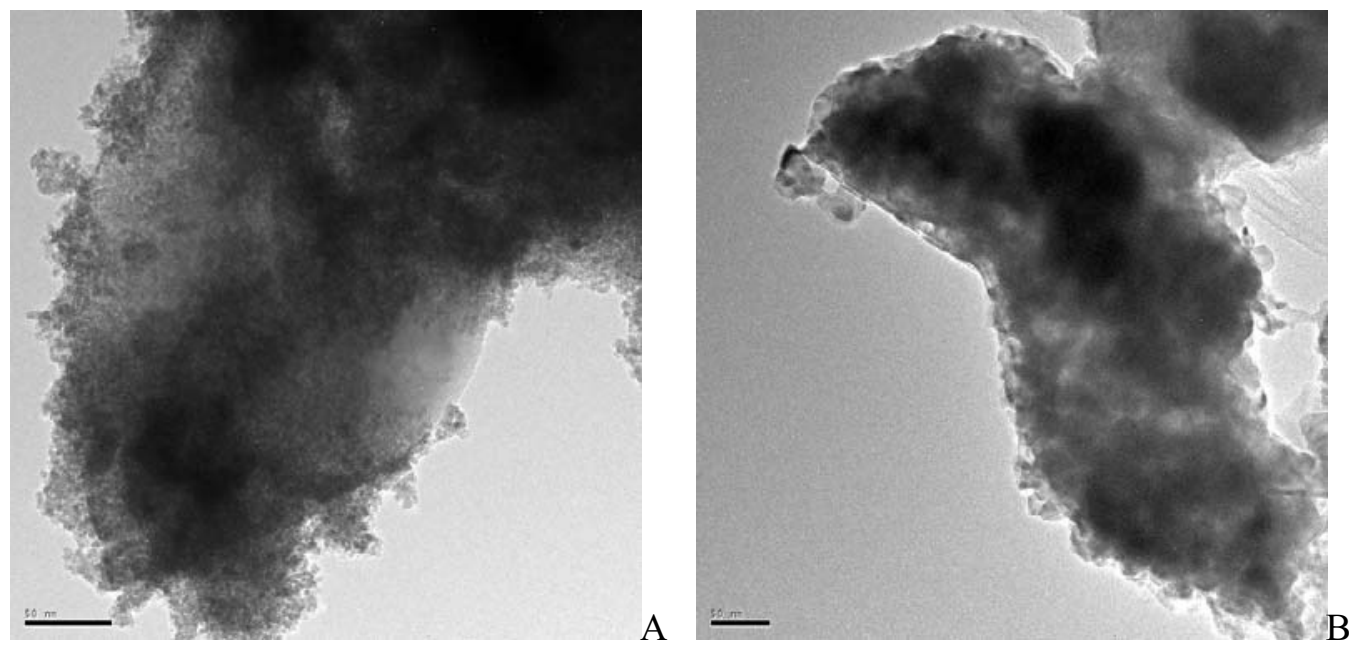

Figure 3. TEM micrographs of calcined samples. A) After infiltration three times and calcination in air at $350{ }^{\circ} \mathrm{C}$ for $4 \mathrm{~h}$ between each infiltration. B) After further calcination at $650{ }^{\circ} \mathrm{C}$ in $9 \% \mathrm{H}_{2} / \mathrm{N}_{2}$ for $48 \mathrm{~h}$. Scale bars $=50 \mathrm{~nm}$. In both micrographs the STN phase is the large particles and the CGO phase is the small nano crystals.

\section{Electrochemical Characterization}

Examples of impedance spectra obtained at $700-850{ }^{\circ} \mathrm{C}$ in $\mathrm{H}_{2}$ with approximately $3 \% \mathrm{H}_{2} \mathrm{O}$ is given in Figure 4 for the electrodes on the symmetrical cell type STN_CGO-1. In general, the impedance data have been fitted to the equivalent circuit $\mathrm{LR}_{\mathrm{S}}(\mathrm{RQ})_{1}(\mathrm{RQ})_{2}(\mathrm{RQ})_{3}$, following the circuit description codes described elsewhere (20). The inductance, $\mathrm{L}$, is ascribed to the leads and had a typical value of $2 \cdot 10^{-8} \mathrm{H}$ for the current measurement system. $\mathrm{R}_{\mathrm{S}}$ is ascribed to the series resistance of the symmetric cell, originating mainly from the ionic conductivity of the YSZ electrolyte. The magnitude of $\mathrm{R}_{\mathrm{S}}$ was as expected for an YSZ electrolyte of $200 \mu \mathrm{m}$ thickness in the investigated temperature range and the results were consistent for all samples. Figure $4 \mathrm{~b}$ gives an example of the detailed fitting, where three arcs, represented by parallel RQ circuits, are shown as indicated by the resistances $\mathrm{R}_{1}, \mathrm{R}_{2}$, and $\mathrm{R}_{3}$ from high to low frequency. 


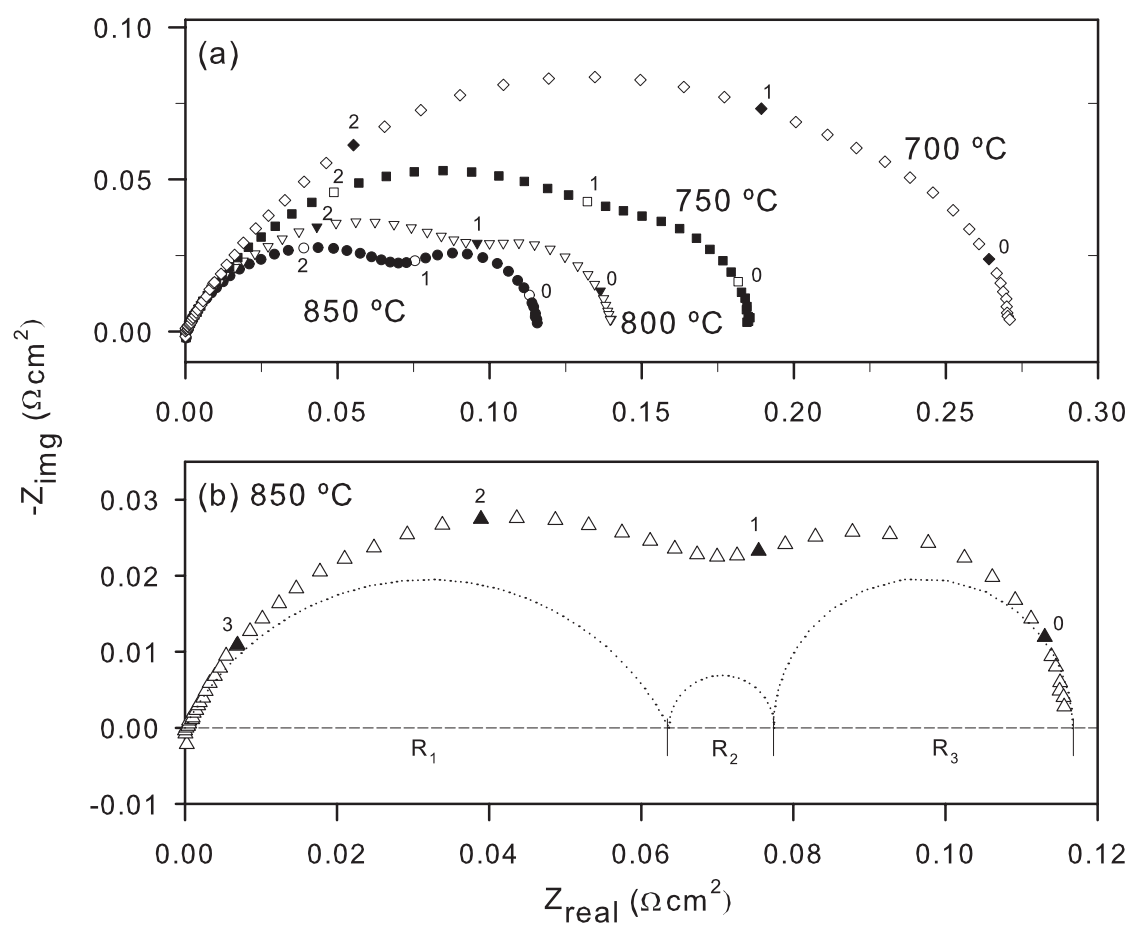

Figure 4. Selected impedance spectra of the STN_CGO-1 symmetrical cell at different temperatures in humidified $\mathrm{H}_{2}$ (approximately $3 \% \mathrm{H}_{2} \mathrm{O}$ ). All impedance spectra are corrected for $\mathrm{R}_{\mathrm{S}}$ and the active electrode area. Points are experimental data and in (b) dotted lines indicate each impedance arc in the fit at $850{ }^{\circ} \mathrm{C}$. Closed symbols (or open symbols) in the figures and the numbers beside them indicate $\log$ (frequency, Hz). The polarization resistance $R_{P}$ is the sum of $R_{1}, R_{2}$, and $R_{3}$.

Each parallel RQ is assumed to correspond to one physical process occurring in the complex electrode reactions, where the total polarization resistance of the electrode, $R_{P}$, is defined as $R_{1}+R_{2}+R_{3}$. The various mechanisms will be discussed in a coming paper.

The electrode polarization resistance $\left(\mathrm{R}_{\mathrm{P}}\right)$ was compared with similar measurements with a Ni/YSZ fuel electrode. The Ni/YSZ electrodes were applied to a similar presintered YSZ electrolyte tape from the same fabrication batch as used for the infiltrated symmetrical cells. The results should therefore be comparable. In order to get a better comparison of the surprisingly high electrochemical performance of the CGO-infiltrated STN ceramic electrode, the results were also compared with single component STN electrodes (i.e. without CGO infiltration) and electrodes with STN/YSZ composite structure (without CGO infiltration) (8). The polarization resistances $\left(\mathrm{R}_{\mathrm{P}}\right)$ at various temperatures for the different electrode compositions are shown in Table III. 
Table III. Polarization resistance $\left(R_{\mathrm{P}}\right)$ in $\mathrm{m} \Omega \mathrm{cm}^{2}$ for different electrode compositions measured with symmetrical cells with same pre-sintered electrolyte $(200 \mu \mathrm{m} \mathrm{YSZ})$ batch. $\mathrm{STN}=\mathrm{Sr}_{0.94} \mathrm{Ti}_{0.9} \mathrm{Nb}_{0.1} \mathrm{O}_{3}, \mathrm{CGO}=\mathrm{Ce}_{0.8} \mathrm{Gd}_{0.2} \mathrm{O}_{2-\delta}$ (infiltrated). LT $=$ measurements at $650^{\circ} \mathrm{C}$ (after about $140 \mathrm{~h}$ ) before the temperature was raised to $850^{\circ} \mathrm{C}$. Measurements were conducted in humidified $\mathrm{H}_{2}$ (approximately $3 \% \mathrm{H}_{2} \mathrm{O}$ ).

\begin{tabular}{lccccccc}
\hline $\begin{array}{l}\text { Electrode } \\
\text { composition }\end{array}$ & $\begin{array}{c}\mathbf{6 5 0}^{\circ} \mathbf{C} \\
(\mathbf{L T})\end{array}$ & $\mathbf{8 5 0}^{\circ} \mathbf{C}$ & $\mathbf{8 0 0}^{\circ} \mathbf{C}$ & $\mathbf{7 5 0}^{\circ} \mathbf{C}$ & $\mathbf{7 0 0}^{\circ} \mathbf{C}$ & $\mathbf{6 5 0}^{\mathbf{}} \mathbf{C}$ & $\mathbf{6 0 0}^{\mathbf{}} \mathbf{C}$ \\
\hline STN (8) & - & 163000 & - & 670000 & - & - & - \\
STN/YSZ (8) & - & 36000 & 94000 & 245000 & - & - & - \\
Ni/YSZ & - & $125 \pm 10$ & - & $275 \pm 20$ & - & $820 \pm 10$ & - \\
STN_CGO-1 & - & $116 \pm 1$ & $139 \pm 3$ & $183 \pm 6$ & $263 \pm 14$ & $442 \pm 20$ & $740 \pm 40$ \\
STN_CGO-2 & $300 \pm 60$ & $140 \pm 5$ & $191 \pm 7$ & $268 \pm 10$ & $399 \pm 16$ & $625 \pm 26$ & - \\
STN(1300)_CGO & - & $289 \pm 38$ & $434 \pm 64$ & $656 \pm 110$ & $1019 \pm 180$ & $1670 \pm 300$ & - \\
STN/YSZ(1300)_CGO & - & $208 \pm 13$ & $334 \pm 41$ & $576 \pm 113$ & $1024 \pm 267$ & - & - \\
\hline
\end{tabular}

Most of the infiltrated ceramic electrodes had similar or even lower polarization resistance $\left(\mathrm{R}_{\mathrm{P}}\right)$ compared to the $\mathrm{Ni} / \mathrm{YSZ}$ electrode at $850{ }^{\circ} \mathrm{C}$. $\mathrm{R}_{\mathrm{P}}$ was lower at decreased temperatures due to surprisingly low activation energy, approximately $0.5-0.7 \mathrm{eV}$ in the temperature region from $600-850{ }^{\circ} \mathrm{C}$. The activation energy can be compared to Ni/YSZ cermets that have activation energies around $0.8 \mathrm{eV}(21)$. The CGO-infiltrated cells had approximately three orders of magnitude lower $\mathrm{R}_{\mathrm{P}}$ compared with single component STN cells, i.e. the cells without infiltration. Another interesting result was the apparently low $\mathrm{R}_{\mathrm{P}}$ at $650{ }^{\circ} \mathrm{C}(\mathrm{LT})$, which was shown in Table III. These measurements were conducted at $650{ }^{\circ} \mathrm{C}$ in humidified $\mathrm{H}_{2}$ during approximately $140 \mathrm{~h}$ before the temperature was raised to $850{ }^{\circ} \mathrm{C}$. This indicates that $\mathrm{R}_{\mathrm{P}}$ is even lower when the maximum temperature, at which the impregnated electrodes are exposed to, is kept relatively low.

In Table III it was shown that $\operatorname{STN}(1300)$ CGO had a relatively poor initial performance, approximately $1.67 \Omega \mathrm{cm}^{2}$ at $650{ }^{\circ} \mathrm{C}$, compared to some other infiltrated cells, e.g. STN_CGO-1 where $R_{P}$ was $0.44 \Omega \mathrm{cm}^{2}$ at $650{ }^{\circ} \mathrm{C}$. However, when the STN(1300)_CGO electrode sample was redox cycled at $650{ }^{\circ} \mathrm{C}$ the cell was activated. Figure 5a shows how the $\mathrm{R}_{\mathrm{P}}$ of STN(1300)_CGO was affected by conducting four redox cycles at different times. Between redox 1 and redox 2 measurements were conducted at temperatures below $650{ }^{\circ} \mathrm{C}$ and between redox 2 and redox 3 measurements were conducted at higher temperatures and various $P\left(\mathrm{O}_{2}\right)$. Figure $5 \mathrm{~b}$ shows a similar redox measurement on the symmetrical cell type STN_CGO-2. 


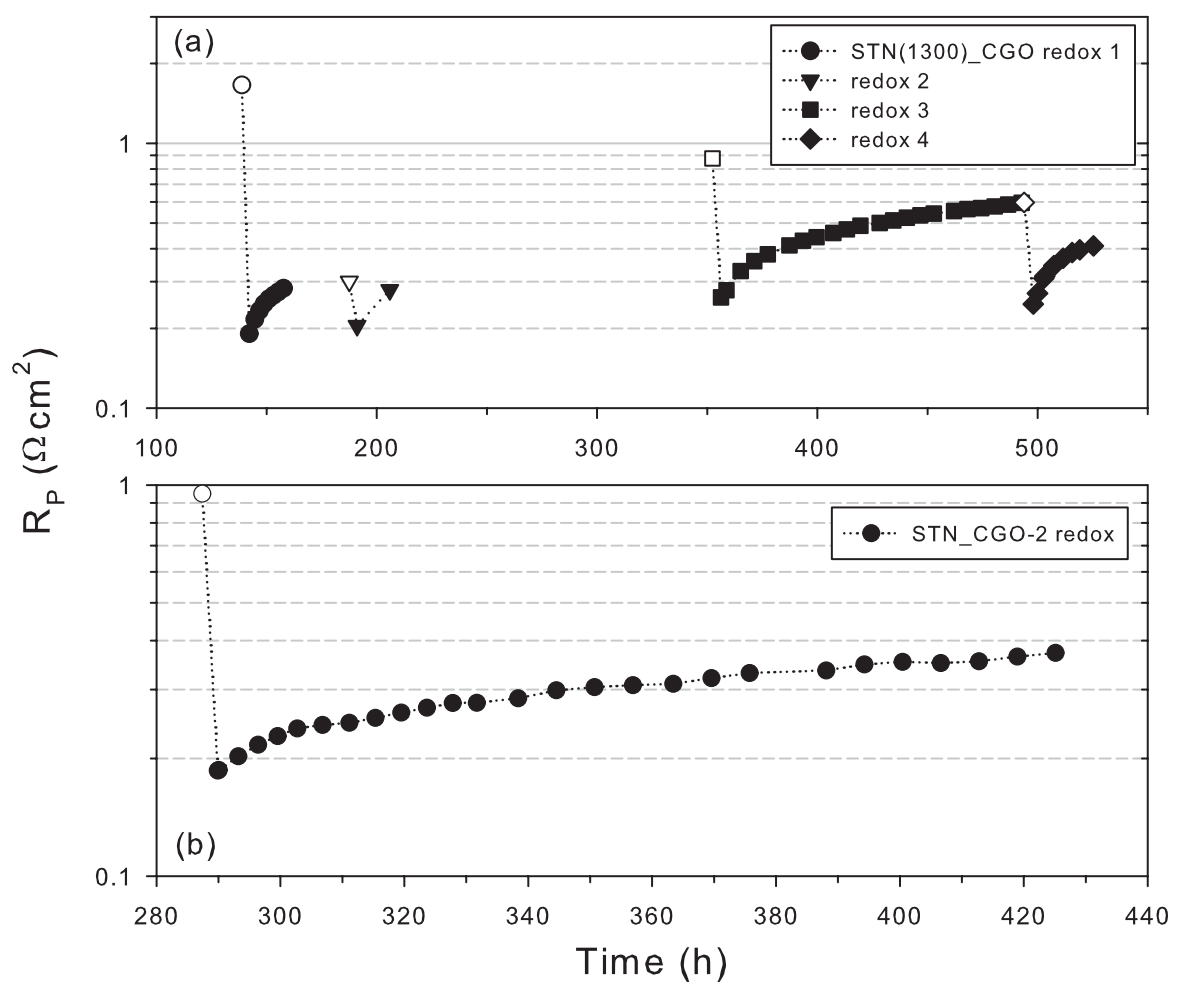

Figure 5. Redox test of different electrodes. (a) STN(1300)_CGO and (b) STN_CGO-2 at $650{ }^{\circ} \mathrm{C}$. Open symbols represent $\mathrm{R}_{P}$ prior to exposure to air. The closed symbols are $\mathrm{R}_{\mathrm{P}}$ as a function of time after re-reduction.

Figure 5 illustrates that even if $R_{P}$ initially was relatively high for these sample series, the polarization resistance initially decreased almost by a factor of 10 for STN(1300)_CGO (from 1.67 to $0.19 \Omega \mathrm{cm}^{2}$ ) after the first redox cycle at $650{ }^{\circ} \mathrm{C}$. Redox cyclings at $650{ }^{\circ} \mathrm{C}$ were repeated on other sample series as well (e.g. STN_CGO-2 in Figure $5 \mathrm{~b}$ ) and the redox activation phenomenon was similar, with an activation of $R_{P}$ down to around $0.2-0.25 \Omega \mathrm{cm}^{2}$ and then stabilization occurred around $0.4-0.6 \Omega \mathrm{cm}^{2}$ at $650{ }^{\circ} \mathrm{C}$. Redox cyclings at higher temperatures have been performed as well. At $750{ }^{\circ} \mathrm{C}$ and $850{ }^{\circ} \mathrm{C}$ the cells did not activate as in the experiments at $650^{\circ} \mathrm{C}$. However, the results indicated that the cells were relatively redox stable with similar $\mathrm{R}_{\mathrm{P}}$ before oxidation and after stabilization during re-reduction.

The microstructure of the various electrodes after electrochemical characterization has been investigated with SEM. The samples have also been analyzed with XEDS to determine the position of the various components. SEM images from STN_CGO-1 is presented in Figure 6. 


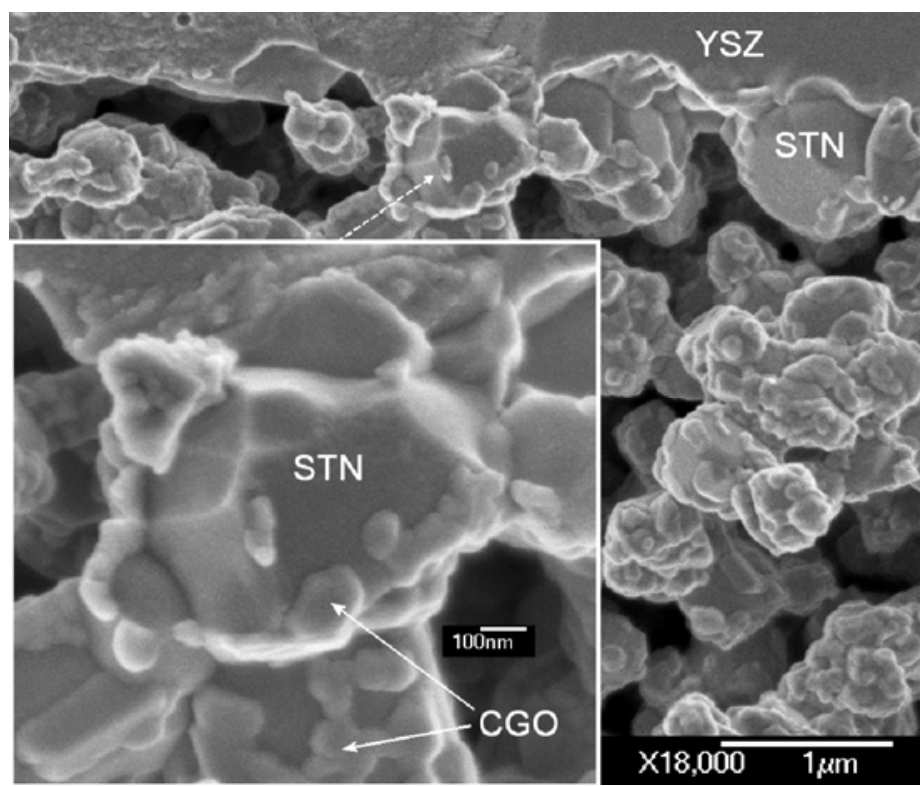

Figure 6. Cross-sectional SEM image of STN_CGO-1 after EIS characterization. The sample had been exposed to a maximum temperature of $850{ }^{\circ} \mathrm{C}$ and was cooled down to room temperature in reducing atmosphere $\left(9 \% \mathrm{H}_{2} / \mathrm{N}_{2}\right)$ to avoid oxidation.

After electrochemical testing, where a maximum temperature of $850{ }^{\circ} \mathrm{C}$ was used, the CGO grains were approximately $30-100 \mathrm{~nm}$. The CGO grains appeared to be somewhat connected in a percolating network partially covering the larger STN particles. The inset in Figure 6 shows that the CGO grains appeared to have formed rather well defined crystallographic facets in some areas on the STN particles.

\section{Discussion}

\section{Sample Characterization}

The addition of a polymeric surfactant to the nitrate precursor solutions facilitated the formation of nano-sized CGO particles at low temperatures. It appears as if ceria-based compounds have a very strong tendency to crystallize, which makes it possible to use low calcination temperatures. Approximately $5 \mathrm{~nm}$ sized CGO crystallites were achieved when the infiltrated samples were calcined in air at $350{ }^{\circ} \mathrm{C}$ for $4 \mathrm{~h}$. It seems as if the surfactant has the effect of complexing the metal ions, so that the individual oxides $\left(\mathrm{CeO}_{2}\right.$ and $\mathrm{Gd}_{2} \mathrm{O}_{3}$ ) do not form prematurely. XRD results confirmed that the composition of the infiltrated phase was the expected $\mathrm{Ce}_{0.8} \mathrm{Gd}_{0.2} \mathrm{O}_{2-\delta}$.

SEM images (Figure 1) and TEM images (Figure 3) showed that after infiltration of the STN backbone structure with the CGO precursor solution and subsequent calcination, a thin CGO film (approximately $50-100 \mathrm{~nm}$ ) formed that covered the whole backbone structure. It is believed that the good surface coverage was achieved due to the ability of the surfactant to improve the surface wetting of the precursor solution. 
The average grain size of the CGO particles was only approximately $16 \mathrm{~nm}$ (calculated from XRD diffractograms) after calcination at $650{ }^{\circ} \mathrm{C}$ in $9 \% \mathrm{H}_{2} / \mathrm{N}_{2}$ for $48 \mathrm{~h}$. These grain sizes were also confirmed by TEM (Figure 3). After a similar heat treatment at $850{ }^{\circ} \mathrm{C}$ the grain size was still relatively low, only about $40 \mathrm{~nm}$. The achieved small grain sizes, even after relatively long calcination times ( $48 \mathrm{~h}$ ), might be explained by a self-limited grain growth mechanism, similar to the results recently reported by Rupp et al. for nano-crystalline ceria ceramics (22). During isothermal grain growth studies they showed that the CGO grains grew within the first $5-10 \mathrm{~h}$ of dwell until metastable microstructures with limited grain sizes were established. The limited grain growth was only observed for temperatures below $1100{ }^{\circ} \mathrm{C}$ and average grain sizes below $140 \mathrm{~nm}$ (22). Since the grain sizes of the CGO phase reported here, are in excellent agreement with the grain sizes reported by Rupp et al. (22) it is probable that the size of the infiltrated CGO particles will remain in the nano to submicron scale even after exposure to higher temperatures, e.g. $850{ }^{\circ} \mathrm{C}$, during long time periods.

\section{$\underline{\text { Electrochemical Characterization }}$}

CGO is a mixed ionic and electronic conductor (MIEC) and it is suggested that the CGO almost exclusively is responsible for the electrocatalytic activity. The STN backbone structure, which is basically only an electronic conductor, is thus believed only to participate in the electrochemistry as a conductor for electrons under reducing atmosphere. The achieved activity of the CGO-infiltrated STN electrodes was good because the CGO phase consists of nano-sized particles even at relatively high temperatures of $850{ }^{\circ} \mathrm{C}$ (as seen in Figure 6), and as a result the $\mathrm{CGO}$ phase will have active surfaces/facets in large numbers. Since CGO is a MIEC, the whole or at least a large part of the exposed surfaces of the nano-sized CGO particles will be more or less electrocatalytically active. Because of this, the performance of the CGO-infiltrated electrodes may exceed that of the Ni/YSZ anodes, especially at temperatures below 850 ${ }^{\circ} \mathrm{C}$. In Ni/YSZ electrodes it is well established that the reactivity is more or less bound to a small area close to the triple phase boundaries. A low SOFC operating temperature will promote smaller CGO particles, larger BET specific surface area (c.f. Table II), and an apparently higher electrochemical activity. The polarization resistance, $\mathrm{R}_{\mathrm{P}}$, at $650{ }^{\circ} \mathrm{C}$ was much lower before exposure to $850^{\circ} \mathrm{C}$ (where the CGO grains grow) compared to after measurements at higher temperatures (c.f. Table III, $650^{\circ} \mathrm{C}(\mathrm{LT})$ ). In general the CGOinfiltrated STN electrodes performed similar or even better than the Ni/YSZ electrodes, when measured on symmetrical cells. It must be mentioned that co-sintered Ni/YSZ anodes, in anode-supported cells, has an anode polarization resistance of about a factor of two lower than those measured here for Ni/YSZ on symmetrical cells (23). This is probably related to the difference in electrode fabrication.

Redox Stability. Redox stability has recently been reported for non-infiltrated STN electrodes (8). The redox tests of CGO-infiltrated STN cells were shown in Figure 5. The results indicated that the infiltrated cells were surprisingly redox stable. They were actually redox activated when the measurements were performed at $650{ }^{\circ} \mathrm{C}$. The surprising activation after redox cycling were shown on three different electrodes (STN_CGO-2, STN(1300)_CGO, and STN_CGO-1 (not presented here)) which suggests that the results are reproducible. The apparent redox activation and stability towards redox cycles is a very promising feature and further experiments are needed to determine the true nature behind the surprising behavior. 


\section{Conclusions}

Unexpectedly high performance, i.e. high electrochemical activity at a wide range of temperatures $\left(600-850^{\circ} \mathrm{C}\right)$, was obtained with a novel ceramic composite anode which was fabricated by a process in which nano-sized ceria particles were provided in a backbone structure of an electronically conductive phase of $\mathrm{Nb}$-doped strontium titanate (nominal composition $\mathrm{Sr}_{0.94} \mathrm{Ti}_{0.9} \mathrm{Nb}_{0.1} \mathrm{O}_{3}=\mathrm{STN}$ ).

Gd-doped ceria was infiltrated in the electronically conductive STN phase, whereby a calcination step was conducted to in-situ form nano-sized ceria particles/crystallites that covered the surface of the electronically conductive backbone structure. The nano-sized CGO particles, which formed due to the presence of a surfactant, were finely dispersed within the electronically conductive phase of STN. When measured on symmetrical cells at open circuit voltage (OCV) in a one-atmosphere set-up, the electrochemical activity was maintained or even improved compared to a Ni/YSZ fuel electrode. The electrocatalytic activity and oxygen ion transport is believed to be provided by the CGO nano-particle network covering the STN backbone structure whereas the STN backbone structure mainly provides electronic conductivity.

Due to the apparently low activation energy of the electrode (around $0.5-0.7 \mathrm{eV}$ ), the sensitivity to temperature changes was reduced and relatively high performance was achieved at a wide range of temperatures (e.g. $600-850^{\circ} \mathrm{C}$ ). High activity is achieved with the CGO-infiltrated electrodes due to the mixed conduction of CGO with nano-sized grains with active facets in large numbers, in contrast to Ni/YSZ anodes in which the activity is more or less constricted to the triple phase boundaries. CGO is presumably not as active as Ni compared per unit area, but since the full area of a large number of CGO nano-particles are present with active surfaces, the STN_CGO electrodes appear to be superior to Ni/YSZ electrodes, when measured on symmetrical cells. It is shown that if the microstructure of ceramic composites is optimized the activity can be enhanced by several orders of magnitude in some cases.

Further, the electrode composition was shown to be redox stable. The electrode was actually activated with redox cycles at $650{ }^{\circ} \mathrm{C}$. As a result of the high redox stability the novel composite anode structure is more robust to changes in the surrounding atmosphere and due to the relatively good dimensional stability of the STN backbone structure in various atmospheres, the electrode structure will not expand or contract much upon oxidation/reduction.

\section{Acknowledgments}

The authors would like to acknowledge financial support by the European Union IPproject Real-SOFC (SES6-CT-2003-502612) and by Energinet.dk through the project PSO 2007-1- 7124 SOFC R\&D. We are grateful to the Fuel Cells and Solid State Chemistry Department at Risø DTU for assistance. 


\section{References}

1. T. Klemensø, C. Chung, P. H. Larsen, M. Mogensen, in SOFC-IX, S. C. Singhal and J.Mizusaki, Editors. The Electrochemical Society Proceedings, p. 1226 Pennington, NJ, (2005).

2. Y. Matsuzaki, I. Yasuda, Solid State Ionics, 132, 261 (2000).

3. A. Atkinson, S. Barnett, R. J. Gorte, J. T. S. Irvine, A. J. Mcevoy, M. Mogensen, S. C. Singhal, J. Vohs, Nat. Mater., 3, 17 (2004).

4. B. A. Boukamp, Nat. Mater., 2, 294 (2003).

5. S. W. Tao, J. T. S. Irvine, Chem. Rec., 4, 83 (2004).

6. O. A. Marina, L. R. Pederson, in Proc. 5th European Solid Oxide Fuel Cell Forum, J. Huijsmans, Editor. European Solid Oxide Fuel Cell Forum, p. 481 Switzerland, (2002).

7. J. C. Ruiz-Morales, J. Canales-Vázquez, C. Savaniu, D. Marrero-López, W. Zhou, J. T. S. Irvine, Nature, 439, 568 (2006).

8. P. Blennow, K. K. Hansen, L. R. Wallenberg, and M. Mogensen, Solid State Ionics, (submitted for publication) (2007).

9. O. A. Marina, N. L. Canfield, J. W. Stevenson, Solid State Ionics, 149, 21 (2002).

10. R. Mukundan, E. L. Brosha, F. H. Garzon, Electrochem. Solid-State Lett., 7, A5A7 (2004).

11. Z. Cheng, S. Zha, M. Liu, J. Electrochem. Soc., 153, A1302-A1309 (2006).

12. Q. X. Fu, F. Tietz, D. Stover, J. Electrochem. Soc., 153, D74-D83 (2006).

13. S. W. Tao, J. T. S. Irvine, Nat. Mater., 2, 320 (2003).

14. S. W. Tao, J. T. S. Irvine, J. Electrochem. Soc., 151, A252-A259 (2004).

15. H. P. He, J. M. Vohs, R. J. Gorte, J. Electrochem. Soc., 150, A1470-A1475 (2003).

16. S. P. Jiang, X. J. Chen, S. H. Chan, J. T. Kwok, J. Electrochem. Soc., 153, A850A856 (2006).

17. X. J. Chen, Q. L. Liu, S. H. Chan, N. P. Brandon, K. A. Khor, Electrochem. Commun., 9, 767 (2007).

18. H. Kurokawa, T. Z. Sholklapper, C. P. Jacobson, L. C. De Jonghe, S. J. Visco, Electrochem. Solid-State Lett., 10, B135-B138 (2007).

19. P. Blennow, K. K. Hansen, L. R. Wallenberg, M. Mogensen, J. Eur. Ceram. Soc., 27, 3609 (2007).

20. B. A. Boukamp, Solid State Ionics, 169, 65 (2004).

21. S. Primdahl, PhD thesis, University of Twente, The Netherlands and Risø National Laboratory, Denmark, 1999.

22. J. L. M. Rupp, A. Infortuna, L. J. Gauckler, Acta Mater., 54, 1721 (2006).

23. R. Barfod, A. Hagen, S. Ramousse, P. V. Hendriksen, M. Mogensen, Fuel Cells, 6, 141 (2006). 